\title{
PEMBERIAN REMISI BAGI NARAPIDANA PELAKU TINDAK PIDANA KORUPSI
}

\author{
Netty Endrawati, Dyah Permatasari \\ 1. Universitas Islam Kadiri, Kediri \\ 2. Dinas Pendapatan Kabupaten Kediri \\ Email: dyahpermatasari321@gmail.com
}

\begin{abstract}
ABSTRAK
Pemberian remisi terhadap narapidana korupsi terdapat suatu pengetatan untuk mendapatkan remisi. Dengan adanya pengetatan pemberian remisi bagi narapidana koruptor masih saja terdapat pro dan kontra. Untuk itu penulis menganalisis syarat pemberian remisi terhadap koruptor apakah bertentangan atau tidak bertentangan dengan pengaturan pemberian remisi pada Undang-undang tentang Pemasyarakatan serta kesesuaian dengan teori tujuan pemidanaan. Penelitian ini menggunakan penelitian hukum normatif.

Syarat pengetatan pemberian remisi koruptor apabila tetap dipertahankan dan tidak mengubah aturan dari Undang - undang tentang Pemasyarakatan, maka dikatakan telah bertentangan dengan Undang - undang tentang Pemasyarakatan. Terkait dengan pemberian remisi bagi narapidana pelaku tindak pidana korupsi jika ditinjau dari teori tujuan pemidanaan terdapat dua pemikiran dalam hal itu.

Kesimpulan dilihat dari sudut hierarki peraturan perundang-undangan maka pengaturan syarat pemberian remisi koruptor dalam Peraturan Pemerintah Nomor 99 Tahun 2012 bertentangan dengan Pasal 5 Undang - undang tentang Pemasyarakatan.

KATA KUNCI : Remisi; Narapidana Korupsi; UU Pemasyarakatan; Teori Pemidanaan.
\end{abstract}

\section{A. PENDAHULUAN}

Pemberian remisi bagi narapidana koruptor pada awalnya diatur dalam PP No. 28 Tahun 2006. Tetapi dengan adanya Peraturan Pemerintah tersebut banyak sekali adanya pro dan kontra dengan pemberian remisi terhadap koruptor. Hal ini dikarenakan menurut masyarakat kejahatan korupsi adalah kejahatan yang paling merugikan bagi pihak manapun jadi mereka menganggap adanya ketidakadilan bagi pihak yang dirugikan.

.Berangkat dari rasa ketidakadilan dari masyarakat maka pemerintah mengeluarkan PP No. 99 Tahun 2012 tentang Perubahan Kedua Atas Peraturan Pemerintah Nomor 32 Tahun 1999 Tentang Syarat Dan Tata Cara Pelaksanaan Hak Warga Binaan Pemasyarakatan. Dalam Peraturan Pemerintah tersebut terdapat penambahan pasal 34 angka (1) tentang syarat mendapatkan remisi. Dimana syarat pemberian remisi terhadap para narapidana koruptor cenderung adanya suatu pengetatan untuk mendapatkan remisi. Hal itu dilakukan untuk menciptakan suatu rasa keadilan bagi masyarakat. Tetapi disisi lain pengetatan pemberian remisi bagi narapidana koruptor masih saja terdapat pro dan kontra karena ada sebagian kalangan yang merasakan bahwa PP No. 32 Tahun 2012 bertentangan dengan Undang - Undang tentang Pemasyarakatan.

Berdasarkan latar belakang tersebut terdapat dua permasalahan yang akan diteliti. Pertama, Persyaratan pemberian remisi bagi narapidana pelaku tindak pidana korupsi yang diatur dalam Pasal 34 (A) PP No 99 Tahun 2012 apakah bertentangan dengan Undang Undang No. 12 Tahun 1995 tentang Pemasyarakatan. Kedua, Apakah pemberian remisi bagi narapidana pelaku tindak pidana korupsi yang diatur dalam Pasal 34 (A) PP No 99 Tahun 2012 sudah sesuai dengan Teori Tujuan Pemidanaan.

Tujuan penelitian ini adalah Untuk mengetahui tentang analisis syarat pemberian remisi terhadap koruptor yang diatur melalui Peraturan Pemerintah Nomor 99 Tahun 2012 bertentangan atau tidak bertentangan dengan pengaturan pemberian remisi pada Undangundang Nomor 12 Tahun 1995 tentang Pemasyarakatan. Serta Untuk mengetahui tentang kesesuaian Peraturan Pemerintah Nomor 99 Tahun 2012 dengan teori tujuan pemidanaan. 


\section{B. METODE PENELITIAN}

\begin{abstract}
Metode penelitian merupakan cara kerja bagaimana menemukan hasil, memperoleh atau menjalankan suatu kegiatan untuk memperoleh hasil yang konkrit. Metode ini kan mengarahkan penelitian tersebut, sehingga peneliti dapat mengungkap kebenaran secara sistematis, metodelogis, dan konsisten. Begitu juga dalam melakukan penelitian hukum yang mana juga memerlukan suatu metode penelitian. Penelitian hukum dilakukan untuk mencari pemecahan atas isu hokum yang timbul. Oleh karena itulah, penelitian hukum merupakan suatu penelitian didalam kerangka know-how di dalam hukum. ${ }^{1}$
\end{abstract}

Dalam penelitian ini adalah menggunakan penelitian hukum normatif, yaitu metode penelitian yang mengacu kepada norma-norma hukum serta kasus-kasus yang pernah melalui dokumen - dokumen ada untuk memahami penerapan norma-norma hukum terhadap fakta-fakta yang tersaji yang keberadaannya diperuntukkan mengubah keadaan dan menawarkan penyelesaian yang berpotensi untuk menyelesaikan setiap masalah hukum dan kemasyarakatan yang konkret.

Dalam mengumpulkan sumber hukum yang digunakan untuk menyusun penelitian ini, penulis melakukan studi kepustakaan dengan membaca tulisan-tulisan yang berhubungan dengan topik yang dibahas, yang terdapat dalam buku-buku, tulisan-tulisan dalam jurnal, surat kabar, majalah, makalah hasil seminar, dan artikel ilmiah. Sumber hukum yang diperoleh kemudian diolah dan di analisis dengan maksud memberikan gambaran yang komprehensif mengenai tema penelitian ini.

Dalam penelitian ini penulis mendeskripsikan pengaturan remisi secara umum, serta analisis melalui pendekatan yang menggunakan logika untuk menarik satu atau lebih kesimpulan (conclusion) berdasarkan seperangkat premis yang diberikan dari sesuatu yang umum ke sesuatu yang khusus, dalam hal ini berupa rujukan atas aturan aturan yang terdapat pada bahan hukum primer.

${ }^{1}$ Peter mahmud, 2013, Penelitian bukum, Kencana
Prenada Media Group, Jakarta, h 83.

\section{PEMBAHASAN}

1. Persyaratan Pemberian Remisi Bagi Narapidana Pelaku Tindak Pidana Korupsi dikaitkan Dengan Undang Undang No. 12 Tahun 1995 Tentang Pemasyarakatan

Negara Indonesia adalah negara hukum sebagaimana diatur didalam Pasal 1 Ayat 3 Undang-Undang Dasar Negara Republik Indonesia Tahun 1945 (UUD NRI 1945). Salah satu ciri negara hukum adalah perlindungan terhadap hak-hak warga negaranya. Perlindungan ini tidak memandang pada ras, suku, agama, etnik, status sosial hingga status hukum, sehingga pemenuhan terhadap perlindungan hak ini haruslah menjadi suatu prioritas. ${ }^{2}$ Status hukum disini mengacu pada apakah warga negara itu merupakan terpidana atau bukan. Negara tidak boleh mengacuhkan apalagi meniadakan hak-hak terpidana sebagai warga negaranya melainkan harus melindungi hak tersebut tanpa ada kecualinya. ${ }^{3}$

Remisi merupakan hak narapidana. Undang-undang Pemasyarakatan telah memberikan suatu hak bagi narapidana yang salah satunya adalah hak untuk mendapatkan remisi atau pengurangan hukuman yang diatur dalam Pasal 14 ayat

(1) huruf i Undang-undang tentang Pemasyarakatan. Setiap narapidana berhak untuk mendapatkan pengurangan hukuman (remisi) apabila telah memenuhi syarat yang ada yang diatur dalam Pasal 34Peraturan Pemerintah Nomor 99 Tahun 2012. Khusus untuk narapidana korupsi juga harus memenuhi Pasal 34A ayat (1) huruf a dan b Peraturan Pemerintah Nomor 99 Tahun 2012.

Adanya pengaturan khusus terhadap narapidana tindak pidana korupsi bukanlah untuk mendiskriminasi narapidana tindak pidana korupsi. Hal ini dimaksudkan karena sesuai dengan konsideran menimbang dalam PP No.99 Tahun 2012, korupsi merupakan kejahatan luar biasa yang mempunyai akibat

2 Hamid Basyaib, 2006, Membela Kebebasan Percakapan tentang Demokrasi Liberal, Pustaka Alvabet dan Freedom Institute, Jakarta, h. 145 3 YLBHI dan PSHK, 2007, Panduan Bantuan Hukum di Indonesia: Pedoman Anda Memahami dan Menyelesaikan Masalah Hukum, YLBHI, Jakarta, h. 237 
yang begitu besar terhadap negara dan berdampak luas. Tindak pidana korupsi adalah permasalahan terbesar negara Indonesia yang mungkin tidak akan pernah ada habisnya. Sehingga melalui syarat-syarat pemberian remisi terhadap narapidana tindak pidana korupsi yang diperketat dalam PP No. 99 Tahun 2012 bermaksud untuk mencegah agar narapidana tindak korupsi tidak mudah untuk bebas begitu saja.

Penerapan aturan pemberian remisi pada Peraturan Pemerintah Nomor 99 Tahun 2012 merupakan salah satu upaya terpenuhinya asas legalitas dalam hukum pidana. Menurut penulis bahwa adanya pengaturan pengetatan syarat pemberian remisi bagi narapidana korupsi yang diatur dalam Peraturan Pemerintah Nomor 99 Tahun 2012 tidak melihat dari sisi hierarki peraturan perundang-undangan yang berlaku di Indonesia yang telah diatur dalam Pasal 7 Undang-undang Nomor 12 Tahun 2011 Tentang Pembentukan Peraturan Perundangundangan.

Kebijakan penerapan Peraturan Pemerintah Nomor : 99 Tahun 2012 dinilai Bertentangan dengan Undang- undang Nomor : 12 Tahun 1995 Tentang Pemasyarakatan. Sehingga terjadi kontradiksi antara peraturan yang lebih tinggi dengan peraturan yang lebih rendah ( norma konflik ). Terutama rumusan Pasal 34A Ayat (1) PP Nomor : 99 Tahun 2012 bertentangan dengan Pasal 5 UU Nomor : 12 Tahun 1995 Tentang Pemasyarakatan yang melarang adanya pembedaan perlakuan dan pelayanan terhadap narapidana yang artinya semua bentuk perlakuan dan pelayanan harus sama dan tidak ada unsur diskriminasi.

Selain itu juga Syarat pemberian remisi koruptor yang terdapat dalam Pasal $34 \mathrm{~A}$ ayat (1) huruf adan b Peraturan Pemerintah Nomor 99 Tahun 2012 ini apabila dicermati lebih dalam arti dari syarat pemberian remisi ini juga bertentangan dengan Pasal 28 D ayat (1) UUD NRI Tahun 1945 yang berbunyi:

"Setiap orang berbak atas pengakuan, jaminan, perlindungan, dan kepastian bukum yang adil serta perlakuan yang sama di hadapan bukum."
Pembatasan pengetatan pemberian remisi jugabertentangan dengan Pasal $28 \mathrm{~J}$ UUD NRI Tahun 1945 yang berbunyi:

(1) Setiap orang wajib menghormati hak asasi manusia orang lain dalam tertib kehidupan bermasyarakat, berbangsa, dan bernegara.

(2) Dalam menjalankan hak dan kebebasannya, setiap orang wajib tunduk kepada pembatasan yang ditetapkan dengan Undang-undang dengan maksud semata-mata untuk menjamin pengakuan serta penghormatan atas hak dan kebebasan orang lain dan untuk memenuhi tuntutan yang adil sesuai dengan pertimbangan moral,nilai-nilai agama, keamanan, dan ketertiban umum dalam suatu masyarakat demokratis.

Sebagaimana diatur dalam Pasal $28 \mathrm{~J}$

UUD Negara Republik Indonesia Tahun 1945 yang menyebutkan bahwa tidak dibenarkan adanya pembatasan hak asasi manusia yang perumusannya diatur dalam ketentuan Peraturan Pemerintah. Jika pun dikehendaki ada pembatasan, seharusnya di lakukan dengan Undang - undang karena di sebutkan secara tegas bahwa pembatasan hak asasi manusia hanya dapat dilakukan dengan undang- undang dan tidak boleh dengan peraturan perundang- undangan di bawahnya.

Syarat pengetatan pemberian remisi koruptor apabila tetap dipertahankan dan tidak mengubah aturan dari Undang - undang tentang Pemasyarakatan, maka Peraturan Pemerintah Nomor 99 Tahun 2012 dikatakan telah bertentangan dengan UUD NRI Tahun 1945 dan Undang - undang tentang Pemasyarakatan. Ini berarti dapat dikatakan bahwa kita melanggar konstitusi yang seharusnya mewajibkan kita semua menaati hierarki peraturan perundang-undangan. $\mathrm{Hal}$ tersebut juga dapat dikatakan bahwa Undangundang tentang Pemasyarakatan bertentangan dengan UUD NRI Tahun 1945, karena seharusnya dalam melakukan pembatasan hak asasi narapidana kejahatan luar biasa khususnya korupsi, pengaturan khusus hak remisi koruptor juga harus diatur dalam Undang-undang tentang Pemasyarakatan secara lebih rinci, bukan hanya sekedar terdapat syarat pemberian remisi koruptor yang diperketat dari aturan 
sebelumnyayang keluar dari norma dasar Undang-undang tentang Pemasyarakatan. ${ }^{4}$

Oleh karena itu apabila terdapat pembatasan syarat pemberian remisi koruptor, maka hak narapidana berupa remisi yang diatur dalam Undang-undang tentang Pemasyarakatan inipun juga harus diperbaiki klausul aturannya, sehingga terjadi harmonisasi antara Undang-undang tentang Pemasyarakatan yang mengatur hak remisi bagi setiap narapidana dengan Peraturan Pemerintah yang mengatur selebihnya syaratsyarat yang harus dipenuhi oleh setiap narapidana yang akan mendapatkan remisi.

\section{Pemberian Remisi Bagi Narapidana Pelaku Tindak Pidana Korupsi Yang Diatur Dalam PP No 99 Tahun 2012 Dikaitkan Dengan Teori Tujuan Pemidanaan}

Didalam teori hukum pidana, dikenal setidaknya tiga teori dasar yang memberikan penggambaran mengenai tujuan pemidanaan, yaitu: teori absolut, teori relatif dan teori gabungan. ${ }^{5}$ Namun, dalam penerapannya tidak ada penggunaan satu teori secara mutlak. Pada akhirnya berdasarkan teori-teori ini dan perkembangan zaman, disarikan tujuan pemidanaan, yaitu: untuk memperbaiki pribadi penjahat sendiri, membuat orang jera untuk melakukan tindak pidana, membuat penjahat tertentu tidak mampu melakukan tindak pidana tertentu, ${ }^{6}$ serta memberikan suatu efek jera (deterrence effect) bagi pelaku tindak pidana. ${ }^{7}$

Tujuan pemidanaan dapat tercapai dengan mekanisme pengaturan para terpidana yang sesuai dengan karakter dan sifat masing-masing tindak pidana. Dalam hal

4 Abdul Madjid, S.H., M.H.,dan Eny Harjati, S.H., M.H., Analisis Yuridis Kedudukan Peraturan Pemerintab Nomor 99 Tabun 2012 Terbadap Kebijakan Pengetatan Pemberian Remisi Bagi Narapidana Korupsi Sebagai Bentuk Penanggulangan Tindak Pidana Korupsi Di Indonesia, Analisa Ilmiah Fakultas Hukum Universitas Brawijaya, h.8.

5 Yesmil Anwar dan Adang, 2008, Pembaruan Hukum Pidana: Reformasi Hukum, Grasindo, Jakarta, h. 137-138.

6 Tina Asmarawati, 2015, Pidana dan Pemidanaan dalam Sistem Hukum di Indonesia (Hukum Penitensier), Deepublish, Yogyakarta, h. 82

7 Saldi Isra, 2009, Catatan Hukum Saldi Isra Kekuasaan dan Perilaku Korupsi, Penerbit Buku Kompas, Jakarta, h. 60. ini, korupsi, telah dijelaskan pada bagian sebelumnya merupakan tindak pidana luar biasa, artinya disini diperlukan suatu penanganan yang luar biasa agar tujuan pemidanaan menjadi dapat terwujud. Namun, hal ini akan menjadi suatu angan-angan saja apabila negara tidak membuat kebijakan yang secara tergas terkait remisi korupsi. Remisi yang pada hakikatnya adalah pengurangan masa tahanan atau suatu "diskon" bagi terpidana. ${ }^{8}$

Terkait dengan pemberian remisi bagi narapidana pelaku tindak pidana korupsi yang diatur dalam Pasal 34 (A) PP No 99 Tahun 2012 tentang Syarat Dan Tata Cara Pelaksanaan Hak Warga Binaan Pemasyarakatan jika ditinjau dari teori tujuan pemidanaan terdapat dua pemikiran dalam hal itu.

Yang pertama jika pemberian remisi dikaitkan dengan salah satu teori pemidanaan yang dikenal adalah teori relatif, yang menekankan pada tujuan pemidanaan untuk memperbaiki pelaku kejahatan. Dengan diberikan pemidanaan ini, diharapkan bahwa nantinya seorang pelaku kejahatan dapat berubah menjadi sosok yang lebih baik lagi dan untuk memulihkan keseimbangan yang rusak karena dilakukannya kejahatan. Perubahan tujuan pemidanaan dari konsep balas dendam telah berubah di Indonesia sejak tahun 1964, sehingga munculah sistem "kepenjaraan" baru yang dikenal dengan Sistem Pemasyarakatan. ${ }^{9}$ Inti dari teori ini telah diadopsi didalam sistem permasyarakatan Indonesia sebagaimana dapat dilihat didalam bagian menimbang huruf (c), Undang-Undang tentang Pemasyarakatan yang menyatakan,

"babwa sistem pemasyarakatan sebagaimana dimaksud dalam buruf $b$, merupakan rangkaian penegakan bukum yang bertujuan agar Warga Binaan Pemasyarakatan menyadari kesalahannya, memperbaiki diri, dan tidak mengulangi tindak pidana sehingga dapat diterima kembali oleh lingkungan masyarakat, dapat aktif berperan dalam pembangunan, dan dapat

\footnotetext{
8 Redaksi RAS, 2010, Tip Hukum Praktiks: Menghadapi Kasus Pidana, Raih Asa Sukses, Depok, h. 165.

9 Romli Atmasasmita, 1975, Dari Pemenjaraan ke Pembinaan Narapidana, Alumni, Bandung, h. 72
} 
hidup secara wajar sebagai warga yang baik dan bertanggung jawab"

Dalam hal ini, pemberian remisi dalam sistem pemasyarakatan Indonesia ditempatkan sebagai suatu motivasi untuk membina diri sendiri. Sebab, remisi tidak lagi sebagai hukum seperti dalam suatu sistem pemasyaraktan, tidak pula sebagai anugerah sebagaimana dalam sistem kepenjaraan, tetapi sebagai hak dan kewajiban yang dimiliki oleh narapidana. Artinya, jika narapidana termasuk untuk tindak pidana korupsi benar-benar melaksanakan kewajibannya, ia berhak mendapat remisi. ${ }^{10}$

Sedangkan pendapat kedua menyatakan, bahwa peraturan yang berlaku bagi terpidana korupsi ada syarat-syarat khusus sebelum mendapatkan remisi, namun sebenarnya syarat yang seperti apapun hendak dijadikan dasar remisi hanya akan membuat pencapaian tujuan pemidanaan terhambat. Pasalnya, korupsi yang pada hakikatnya adalah delik ekonomi yang merugikan negara dan menguntungkan diri sendiri dilakukan berdasarkan keserakahan, dimana dengan mekanisme remisi maka akan ada perhitungan-perhitungan yang nantinya akan mempercepat seorang terpidana korupsi keluar dari lembaga pemasyarakatan.

Perhitungan ini dapat dihitung secara ekonomis oleh koruptor, dan dibandingkan dengan jumlah korupsi yang telah dilakukan, akan membuat terpidana korupsi akan secara tenang menikmati masa tahanannya karena tahu adanya suatu percepatan yang dapat diterimanya akan membuat perhitungan uang hasil korupsi dibandingkan kerugian selama mendekam dalam masa tahanan tetap saja memberikan keuntungan. Belum lagi sistem lembaga pemasyarakatan dewasa ini yang memanjakan terpidana korupsi dengan fasilitas hotel berbintang. ${ }^{11}$

Pada akhirnya, vonis pidana yang dijatuhkan hakim pada terpidana korupsi tidak akan tepat sasaran, karena efek jera yang hendak diberikan guna si terpidana korupsi melakukan perbaikan diri tidak tercapai, sebab terpidana tersebut dapat terus

10 CL Harsono, 1995, Sistem Baru Pembinaan Narapidana, Djambatan, Jakarta, h. 25

11 Denny Indrayana, 2008, Negeri Para Mafioso Hukum di Sarang Koruptor, Penerbit Buku Kompas, Jakarta, h. 77 mengalami pengurangan masa tahanan dan tujuan pemidanaanpun tidak tercapai. Hal ini juga berlaku bagi para calon koruptor yang dengan melihat bahwa remisi akan menjadi alat untuk keluar dari lembaga pemasyarakatan dengan mudah sehingga anasir hukuman, ${ }^{12}$ yang berguna untuk menakut-nakuti sesorang agar tidak melakukan tindak pidana menjadi berkurang dan pada akhirnya ditakutkan peningkatan korupsi menjadi sulit dibendung. Selain itu, sebenarnya Sistem Pemasyarakatan Indonesia mengandung arti pembinaan narapidana yang berintegritas dengan masyarakat dan menuju kepada integritas kehidupan dan penghidupan. Pemasyarakatan sebagai proses bergerak dengan menstimulir timbulnya dan berkembangnya self-propelling adjusment menuju ke arah perkembangan pribadi melalui asosiasinya sendiri menyesuaikan dengan integritas kehidupan dan penghidupan. ${ }^{13}$ Pengurangan masa tahanan yang akan mengurangi efek juga juga mengurangi esensi penting dari sistem pemasyarakatan yaitu masa tahanan adalah masa pembinaan, mengingat karakterikstik tindak pidana korupsi yang luar biasa ini.

Perlu diperhatikan bahwa sebenarnya penolakan terhadap pemberian remisi bagi terpidana korupsi bukanlah suatu bentuk pelanggaran terhadap hak terpidana. Namun, yang dilakukan adalah pemberian standar yang lebih tinggi dalam pemberian remisi yang kemudian menghilangkan terpidana korupsi dari definsi terpidana yang memiliki hak untuk mendapatkan remisi sebagai solusi untuk menangani permasalahan tindak pidana korupsi.

\section{KESIMPULAN}

Jika kita melihat dari sudut hierarki peraturan perundang-undangan, maka pengaturan syarat pemberian remisi koruptor dalam Peraturan Pemerintah Nomor 99 Tahun 2012 bertentangan dengan Pasal 5 Undang - undang tentang Pemasyarakatan.

${ }^{12}$ Alfred Hutauruk dan Marulan Hutauruk, 1961, Garis Besar Tata Hukum Indonesia, Erlangga, Jakarta, h. 68.

13 Bambang Poernomo, 1986, Pelaksanaan Pidana Penjara Dengan Sistem Pemasyarakatan, Liberty, Yogyakarta, h. 186 
Hal itu karena substansi yang terdapat dalam Pasal 34A ayat (1) huruf a dan b Peraturan Pemerintah tersebut merupakan norma baru yang bertentangan dengan filosofi, tujuan, visi dan misi Undang-undang tentang Pemasyarakatan itu sendiri yang melarang adanya perlakuan dan pelayanan diskriminatif terhadap narapidana. Sedangkan disini secara jelas bahwa munculnya revisi Peraturan Pemerintah yang baru ini yaitu Peraturan Pemerintah Nomor 99 Tahun 2012 menimbulkan diskriminasi bagi masyarakat dan narapidana karena adanya perbedaan syarat pemberian remisi yang signifikan dibandingkan dengan Peraturan Pemerintah sebelumnya yaitu Peraturan Pemerintah Nomor 28 Tahun 2006. Oleh karena agar bisa terjadi suatu harmonisaasi perlu di adakannya perubahan klausul aturan pemberian remisi dalam Undang - undang Pemasyarakatan sehingga perubahan syarat pemberian remisi telah sejalan dengan maksud dari diberikannya hak remisi bagi narapidana dalam Undang-undang tentang Pemasyarakatan dan aturan syarat memperoleh remisi koruptor dalam Peraturan Pemerintah Nomor 99 Tahun 2012.

Pemberian remisi bagi terpidana korupsi yan diatur dalam Peraturan Pemerintah No. 99 Tahun 2012 tentang Perubahan Kedua atas Peraturan Pemerintah No. 32 Tahun 1999 tentang Syarat dan Tata Cara Pelaksana Hak Warga Binaan Pemasyarakatan menimbulkan berbagai reaksi di masyarakat yang pro dan kontra terhadap pemberian remisi bagi terpidana korupsi. Pandangan yang pro terhadap pemberian remisi bagi terpidana korupsi melihat bahwa remisi merupakan hak dasar setiap terpidana yang harus dijamin akses terhadap haknya oleh Indonesia sebagai negara hukum. Selain itu, hal ini juga sesuai dengan tujuan pemidanaan relatif. Bahkan sesungguhnya, pencabutan hak remisi bagi terpidana korupsi merupakan bentuk ketidakadilan dan diskriminasi terhadap terpidana. Pandangan yang kontra terhadap pemberian remisi bagi terpidana korupsi mendasari pendiriannya berdasarkan kategorisasi korupsi sebagai tindak pidana luar biasa yang membutuhkan cara penanggulangan yang luar biasa pula. Di sisi lain, terdapat cara pandang bahwa pemberian remisi bagi terpidana korupsi justru bertentangan dengan tujuan pemidanaan dari segi masa pembinaan di dalam lembaga permasyarakatan.

\section{E. DAFTAR PUSTAKA}

Abdul Madjid, S.H., M.H.,dan Eny Harjati, S.H., M.H., Analisis Yuridis Kedudukan Peraturan Pemerintah Nomor 99 Tabun 2012 Terbadap Kebijakan Pengetatan Pemberian Remisi Bagi Narapidana Korupsi Sebagai Bentuk Penanggulangan Tindak Pidana Korupsi Di Indonesia, Analisa Ilmiah Fakultas Hukum Universitas Brawijaya.

Alfred Hutauruk dan Marulan Hutauruk, 1961, Garis Besar Tata Hukum Indonesia, Erlangga, Jakarta.

Bambang Poernomo, 1986, Pelaksanaan Pidana Penjara Dengan Sistem Pemasyarakatan, Liberty, Yogyakarta.

CL Harsono, 1995, Sistem Baru Pembinaan Narapidana, Djambatan, Jakarta.

Denny Indrayana, 2008, Negeri Para Mafioso Hukum di Sarang Koruptor, Penerbit Buku Kompas, Jakarta.

Hamid Basyaib, 2006, Membela Kebebasan Percakapan tentang Demokrasi Liberal, Pustaka Alvabet dan Freedom Institute, Jakarta.

Peter mahmud, 2013, Penelitian bukum, Kencana Prenada Media Group, Jakarta.

Redaksi RAS, 2010, Tip Hukum Praktiks: Menghadapi Kasus Pidana, Raih Asa Sukses, Depok.

Romli Atmasasmita, 1975, Dari Pemenjaraan ke Pembinaan Narapidana, Alumni, Bandung.

Saldi Isra, 2009, Catatan Hukum Saldi Isra Kekuasaan dan Perilaku Korupsi, Penerbit Buku Kompas, Jakarta.

Tina Asmarawati, 2015, Pidana dan Pemidanaan dalam Sistem Hukum di Indonesia (Hukum Penitensier), Deepublish, Yogyakarta.

YLBHI dan PSHK, 2007, Panduan Bantuan Hukum di Indonesia: Pedoman Anda Memabami dan Menyelesaikan Masalab Hukum, YLBHI, Jakarta. 